University of Montana

ScholarWorks at University of Montana

6-1999

\title{
Mycorrhizae Indirectly Enhance Competitive Effects of an Invasive Forb on a Native Bunchgrass
}

Marilyn J. Marler

Catherine A. Zabinski

Ragan M. Callaway

University of Montana - Missoula, Ray.Callaway@mso.umt.edu

Follow this and additional works at: https://scholarworks.umt.edu/biosci_pubs

Part of the Biology Commons

Let us know how access to this document benefits you.

\section{Recommended Citation}

Marler, Marilyn J.; Zabinski, Catherine A.; and Callaway, Ragan M., "Mycorrhizae Indirectly Enhance Competitive Effects of an Invasive Forb on a Native Bunchgrass" (1999). Biological Sciences Faculty Publications. 226.

https://scholarworks.umt.edu/biosci_pubs/226

This Article is brought to you for free and open access by the Biological Sciences at ScholarWorks at University of Montana. It has been accepted for inclusion in Biological Sciences Faculty Publications by an authorized administrator of ScholarWorks at University of Montana. For more information, please contact scholarworks@mso.umt.edu. 


\title{
MYCORRHIZAE INDIRECTLY ENHANCE COMPETITIVE EFFECTS OF AN INVASIVE FORB ON A NATIVE BUNCHGRASS
}

\author{
Marilyn J. Marler, ${ }^{1}$ Catherine A. Zabinski, and Ragan M. Callaway \\ Division of Biological Sciences, University of Montana, Missoula, Montana 59812 USA
}

\begin{abstract}
Mycorrhizae are important mediators of plant competition, but little is known about the role of mycorrhizae in the intense competitive effects that exotic plants can have on native species. In the greenhouse, we tested the effect of arbuscular mycorrhizal (AM) fungi on interspecific competition between Centaurea maculosa and Festuca idahoensis, on intraspecific competition between individuals of both species, and the growth of $C$. maculosa with either inorganic or organic phosphorus. Mycorrhizae had no direct effect on either species, but mycorrhizae increased $C$. maculosa's negative effect on F. idahoensis. When competing with $C$. maculosa, nonmycorrhizal $F$. idahoensis were $171 \%$ larger than they were when mycorrhizae were present. In a second experiment, $C$. maculosa grown with larger $F$. idahoensis were $66 \%$ larger, in the presence of AM fungi, than when AM fungi were absent. Centaurea maculosa biomass was not affected by AM fungi, in either phosphorus treatment, in the absence of $F$. idahoensis. Root : shoot ratios differed between phosphorus treatments, but this difference seemed to be a result of slower growth in the organic phosphorus treatment. Our results were unusual in that the direct effects of mycorrhizae on both species were weak, but the indirect effect of AM fungi on the interactions between $C$. maculosa and $F$. idahoensis was strong. Our results suggest that AM fungi strongly enhance the ability of $C$. maculosa to invade native grasslands of western North America.
\end{abstract}

Key words: arbuscular mycorrhizal (AM) fungi; Centaurea maculosa; competition; exotic plants; Festuca idahoensis; intermontane grasslands; invasion; mycorrhizae.

\section{INTRODUCTION}

Interactions between pairs of species are often mediated by other species (Kareiva 1994, Miller 1994). Well documented indirect interactions include those between sea otters, kelp and sea urchins (Estes 1978), starfish, molluscs and algae (Paine 1966), parasitic and autotrophic plants (Pennings and Callaway 1996), plants and soil microflora, (van der Putten et al. 1993, Bever 1994) and plants and mycorrhizal fungi (Grime et al. 1987, Hetrick et al. 1989, Hartnett et al. 1993, Bever et al. 1996, Moora and Zobel 1996). Indirect effects often result in a reduction in the competitive ability of one of the directly interacting species, altering the outcome of the pairwise interaction. Arbuscular mycorrhizal (AM) fungi can alter the balance of competition (Hetrick et al. 1989, Allen and Allen 1990, Johnson et al. 1992, Hartnett et al. 1993, Zobel and Moora 1995, Moora and Zobel 1996). This occurs because AM fungi enhance resource acquisition of some host plant species more than others (Caldwell et al. 1985, Allen and Allen 1990), and possibly due to the direct transfer of resources or fixed carbon between individuals by AM fungi (Chiarello et al. 1982, Grime et al. 1987, Walter et al. 1996, Watkins et al. 1996a, b).

The effects that AM fungi have on plant interactions

Manuscript received 22 September 1997; revised 22 May 1998; accepted 22 June 1998.

'E-mail: marler@selway.umt.edu vary with nutrient availability (Allen and Allen 1990, Hetrick et al. 1990, 1992, Johnson et al. 1997). For example, phosphorus availability can significantly affect the host plant's relationship with AM fungi. In natural soils, most phosphorus is found in bound, organic forms that are not directly available for plant use. When inorganic forms of phosphorus are available for direct uptake, or when phosphorus is abundant, fungal symbionts may be suppressed (Koide and Li 1990, Koide and Schreiner 1992, DeLucia et al. 1997) or the symbiont may function as a parasite (Hartnett et al. 1993, Johnson 1993, Koide and Schreiner 1992, Johnson et al. 1997).

Because AM fungi can influence competitive hierarchies, they can have strong impacts on plant community structure. For example, AM fungi affect the successional replacement of nonmycorrhizal plants by mycorrhizal species (Allen and Allen 1984, 1988, Allen et al. 1988, Francis and Read 1994). AM fungi have also been shown to contribute to species coexistence by favoring inferior competitors (Grime et al. 1987, Hetrick et al. 1989, Hartnett et al. 1993, Zobel and Moora 1995, Moora and Zobel 1996). However, they have the potential to contribute to competitive exclusion and to decrease species diversity if AM fungi favor a superior competitor (Allen and Allen 1990).

Exotic plant invasions often provide clear examples of competitive exclusion. While AM fungi may promote diversity among naturally co-occurring plant spe- 
cies, the role of mycorrhizae in mediating interactions between invaders and native species is not well understood (Goodwin 1992). Centaurea maculosa Lam. (Asteraceae) and others in its genus are among the most economically destructive range weeds in western North America (Watson and Renney 1974, Griffith and Lucey 1991). Despite extensive efforts to eradicate them, Centaurea species are spreading at prodigious rates (Muller-Scharer and Schroeder 1993). Field populations of C. maculosa in western Montana are heavily colonized by AM fungi, and colonization levels are higher than some species of native bunchgrasses that it frequently displaces (Marler 1997). In a series of greenhouse experiments, we investigated the direct effects of AM fungi on (1) C. maculosa in different phosphorus treatments, and (2) competitive interactions between $C$. maculosa and the native bunchgrass, Festuca idahoensis Elmer.

\section{Methods}

All experiments were conducted in a naturally lit greenhouse that was supplemented with high-pressure sodium lighting. Photosynthetically active radiation (PAR) was in the range 700-1200 mmol photons $\cdot \mathrm{m}^{-2} \cdot \mathrm{s}^{-1}$ during the $16 \mathrm{~h}$ photoperiod. Temperatures ranged from $18-30^{\circ} \mathrm{C}$ throughout the experiments.

\section{Experiment 1}

To test the effects of AM fungi on competition between plants of the same age, we grew the native bunchgrass $F$. idahoensis and $C$. maculosa in intraspecific and interspecific combinations, with and without AM fungi. Six plants were started at the same time from seed in each of 60 pots. Pots measuring $21.25 \mathrm{~cm}$ in diameter and $27.5 \mathrm{~cm}$ deep were filled with sterile silica sand averaging $0.60-0.85 \mathrm{~mm}$ in diameter. After three weeks, seedlings were selected for uniformity in size and were thinned to two per pot so that neighbors were within $10 \mathrm{~cm}$ of each other. A $2 \mathrm{~cm}$ thick layer of whole field soil (including root fragments) was added as inoculum $6 \mathrm{~cm}$ below the surface of the sand. Field soil was collected from beneath many species of native plants and $C$. maculosa on Mount Sentinel in Missoula, Montana, USA, and was mixed before use. Mycorrhizal colonization levels at this site were measured in 1995, using the methods of McGonigle et al. (1990), and were $44 \%$ for $C$. maculosa and $45 \%$ for $F$. idahoensis (Marler 1997). Nonmycorrhizal treatments received autoclaved field soil and $50 \mathrm{ml}$ of a microbial wash. This solution was prepared by filtering a soil slurry through a $25-\mu \mathrm{m}$ filter paper, which is fine enough to remove mycorrhizal fungal propagules, while allowing other soil microorganisms, including potential pathogenic bacteria and fungi, to pass through the filter (Johnson 1993).

Plants were watered to saturation once per week and received $250 \mathrm{ml}$ of a one-eighth strength Hoagland's solution weekly, modified by the addition of phospho- rus as inositol hexaphosphate. This form is not directly available to plants for uptake, and requires alteration in the soil by mycorrhizal fungi, soil microbes, or root exudates (DeLucia et al. 1997). The final concentration of phosphorus was $1.93 \mu \mathrm{g} / \mathrm{ml}$, which is comparable to levels used by other researchers to investigate effects of mycorrhizal colonization in otherwise sterile substrates (Koide and Li 1990). After three months, we measured the total biomass of roots and shoots for both species and evaluated treatment effects on mycorrhizal colonization of roots.

Biomass of $F$. idahoensis was natural-log-transformed for normality, prior to analysis with a two-way ANOVA for effects of neighbor and AM fungal treatments. Data for root: shoot ratios and C. maculosa biomass was normally distributed and did not require transformation. To determine whether significant differences in root: shoot ratios were due to functional shifts in allocation patterns, or to differences in growth among treatments, we examined the root: shoot ratios allometrically by plotting the natural $\log$ of root biomass against the natural log of shoot biomass for both species (see Coleman et al. 1994). Then, to determine if treatments within an experiment were described by the same linear function, we used an analysis of covariance (ANCOVA) to test for differences in the slopes (interaction between treatment and the natural $\log$ of shoot weight) and $y$-intercepts (natural $\log$ of root weight).

\section{Experiment 2}

The results from the first experiment indicated that small $F$. idahoensis had minimal effects on C. maculosa of the same age. To further examine these interactions we conducted a second experiment, in which $C$. maculosa were grown with large, established $F$. idahoensis neighbors. We grew a single $C$. maculosa from seed in each of 30 pots containing an 8-wk-old $F$. idahoensis. In this experiment, final mean biomass of $F$. idahoenis was $0.525 \mathrm{~g}$, compared to $0.145 \mathrm{~g}$ in the previous experiment. The pots and growth medium were the same as described for the Experiment 1. The grasses were provided field soil inoculum during the establishment period; thus, plants of both treatments had the potential to form mycorrhizae before the experiment began. Fungicide is the only way to establish a nonmycorrhizal treatment with previously infected plants. When C. maculosa seeds were planted, AM fungi were reduced in one half of the pots by adding $300 \mathrm{mg}$ of Bonomyl (Bonide, Bonide Products Incorporated, Yorkville, New York, USA), applied in $100 \mathrm{ml}$ of water per pot (50 mg/kg growth medium). Benomyl, a similar systemic fungicide, applied at this rate has been shown to effectively reduce mycorrhizal colonization in greenhouse soils with negligible direct effects on plants (Hetrick et al. 1989). Since systemic fungicides are not specific and kill saprophytic as well as mutualistic fungi, their use in mycorrhizal studies must be interpreted 
TABLE 1. Experiment 1: ANOVA table for $F$. idahoensis biomass grown in competition with either a conspecific or C. maculosa, and with two AM fungal treatments (present or absent).

\begin{tabular}{lcccc}
\hline \hline \multicolumn{1}{c}{$\begin{array}{c}\text { Source of } \\
\text { variation }\end{array}$} & df & $\begin{array}{c}\text { Mean } \\
\text { square }\end{array}$ & $F$ & $P$ \\
\hline Competitor species & 1 & 3.286 & 4.954 & 0.031 \\
AM fungi & 1 & 1.955 & 2.948 & 0.092 \\
Competitor $\times$ AM & 1 & 4.844 & 7.304 & 0.009 \\
Total & 52 & 0.846 & & \\
\hline
\end{tabular}

with care. We watered and fertilized the plants as in the first experiment, with phosphorus added as inositol hexaphosphate to a final phosphorus concentration of $1.93 \mu \mathrm{g} / \mathrm{ml}$, and reapplied Bonomyl every $3 \mathrm{wk}$. After $7 \mathrm{wk}$, we compared mean total biomass and root: shoot ratio of both species in mycorrhizal and nonmycorrhizal treatments with $t$ tests for significance at $P<0.05$, and we checked for mycorrhizal colonization. Data for both species were normally distributed and did not require transformation. We did not statistically compare the results of Experiment 1 to those of Experiments 2 and 3 , because they were conducted at different times.

\section{Experiment 3}

We tested the direct effects AM fungi on C. maculosa using two different forms of phosphorus. Individual $C$. maculosa were grown from seed in pots of the same size and containing the same medium as in Experiments 1 and 2. Plants were watered weekly with $250 \mathrm{ml}$ of one-eighth strength Hoagland's solution, which was modified by addition of phosphorus $(1.93 \mu \mathrm{g} / \mathrm{ml})$ as either the organic form, inositol hexaphosphate (less available for direct plant uptake), or an inorganic form, potassium dihydrogen phosphate, which is directly available to the plant. The purpose of the inorganic phosphorus treatment was to create conditions in which plants would be less likely to benefit from mycorrhizae. In each phosphorus treatment, there were mycorrhizal and nonmycorrhizal treatments. Fungi were reduced in nonmycorrhizal pots with repeated Bonomyl applications as described for Experiment 2. After $7 \mathrm{wk}$, we measured total biomass and root: shoot ratios for each plant, and we compared the means with two-way ANOVAs for the effects of phosphorus and AM fungi treatments. Data were normally distributed and did not require transformation. Root: shoot ratios for each species were examined allometrically as described for Experiment 1 .

\section{RESUlts \\ Experiment 1}

Arbuscular mycorrhizal fungal hyphae and vesicles were observed in roots of both species in the mycorrhizal treatment $(n=3$, mean colonization $=34 \%)$, but no evidence of mycorrhizal fungi was found in the roots of the nonmycorrhizal treatment ( $n=2$, colo- nization $=0 \%$ ). The competitive effect of $C$. maculosa was much greater in the presence of AM fungi, as indicated by a significant interaction term between competitor species and AM treatments (Table 1). When grown with $C$. maculosa, average $F$. idahoensis biomass was $171 \%$ greater when AM fungi were not present (Fig. 1). AM fungi had no effect on $F$. idahoensis biomass in the absence of C. maculosa (Fig. 1, Table 1). However, there was a significant interaction effect between AM fungi and competitor species on the root: shoot ratio of $F$. idahoensis. When grown with $C$. maculosa, F. idahoensis root: shoot ratio significantly increased when AM fungi were present (Fig. 1, Table 2). The natural $\log$ of root and shoot weights were correlated $\left(r^{2}=0.77\right)$ and neither the slope $(P=0.79)$ nor intercept $(P=0.70)$ differed significantly between AM treatments, indicating that the differences were due

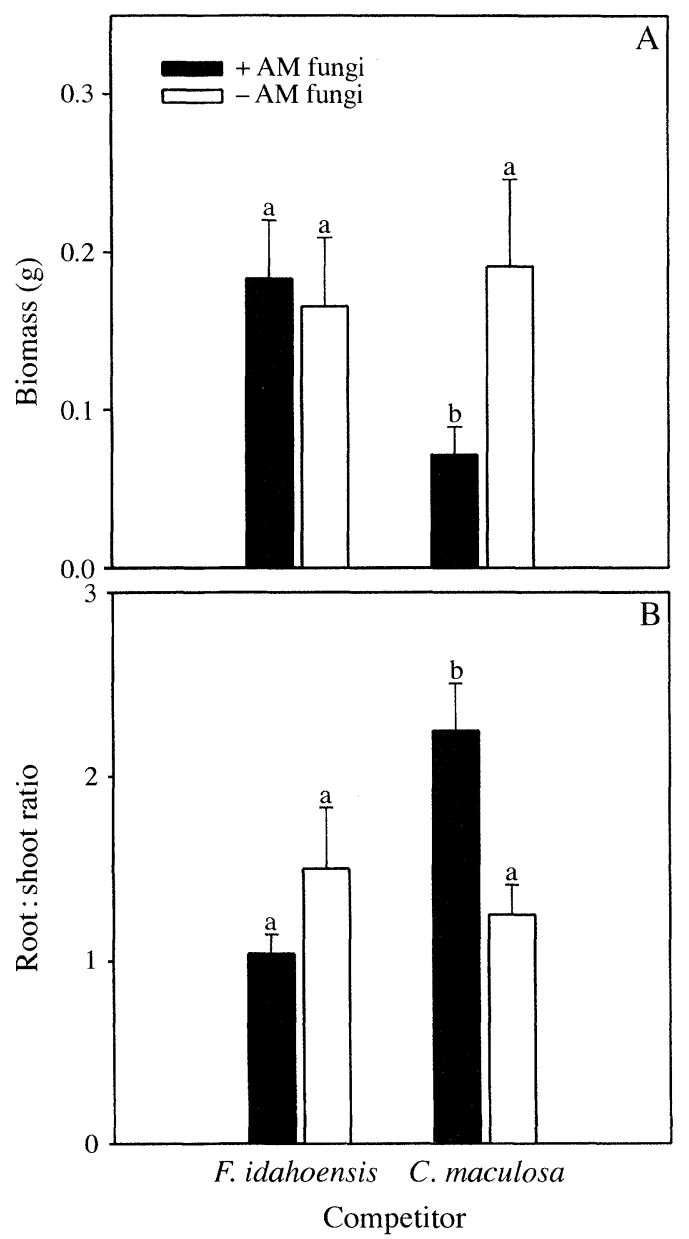

FIG. 1. Experiment 1: Total biomass (A) and root: shoot ratio (B) of $F$. idahoensis when grown with either a conspecific or a C. maculosa plant and with and without arbuscular mycorrhizal (AM) fungi. Error bars represent one standard error of the mean $(+1$ SEM). Bars that share letters were not different at $P<0.05$ (post-ANOVA Tukey test). 
TABLE 2. Experiment 1: ANOVA table for the effect of AM fungi and competition with either a conspecific or C. maculosa on root: shoot ratio of $F$. idahoensis.

\begin{tabular}{lcccc}
\hline \multicolumn{1}{c}{$\begin{array}{c}\text { Source of } \\
\text { variation }\end{array}$} & df & $\begin{array}{c}\text { Mean } \\
\text { square }\end{array}$ & \multicolumn{1}{c}{$F$} & $P$ \\
\hline Competitor species & 1 & 4.449 & 6.610 & 0.013 \\
AM fungi & 1 & 1.909 & 2.836 & 0.099 \\
Competitor $\times$ AM & 1 & 9.039 & 13.432 & 0.001 \\
Total & 52 & 0.970 & & \\
\hline
\end{tabular}

to differences in growth between treatments, and not to allocation differences (Coleman et al. 1994).

Intraspecific competition reduced $C$. maculosa biomass significantly more than interspecific competition (Fig. 2, Table 3). The interaction between AM fungal treatment and competitor species was significant, indicating that the response of C. maculosa to the pres-
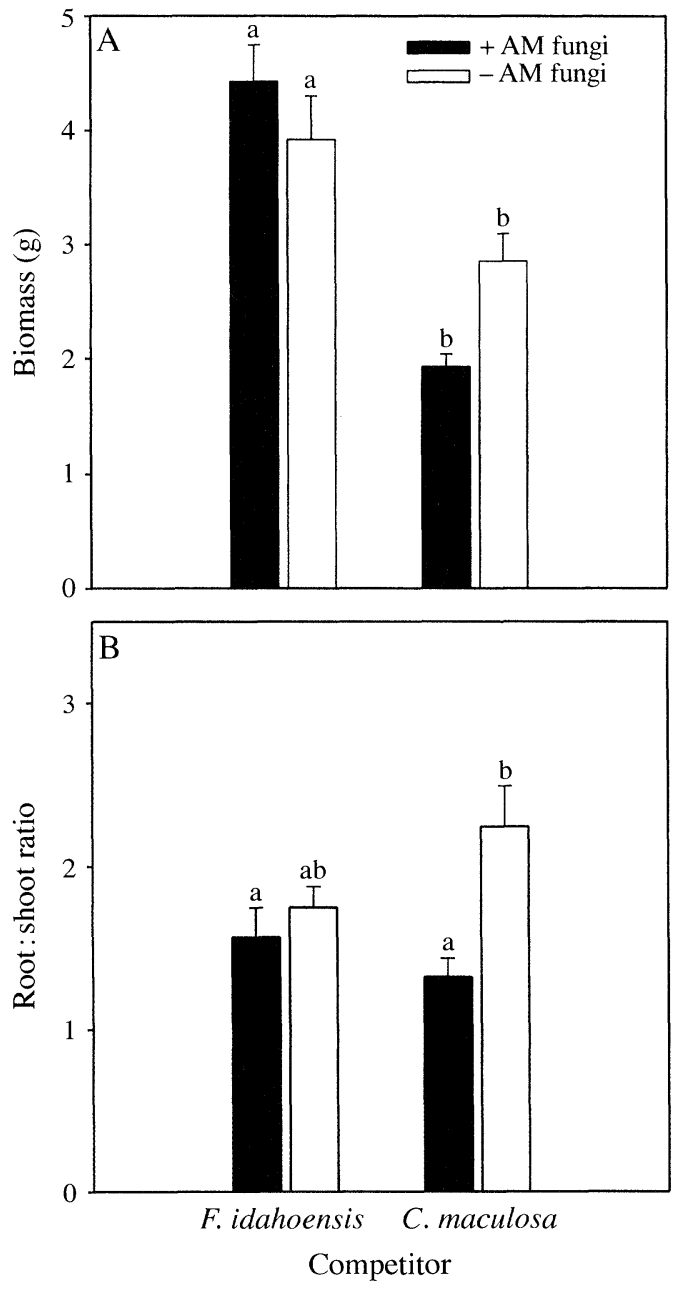

FIG. 2. Experiment 1: Total biomass (A) and root : shoot ratio (B) of $C$. maculosa when grown with either a conspecific or a small $F$. idahoensis plant, and with and without AM fungi. Error bars represent +1 SEM. Bars that share letters were not different at $P>0.05$ (post-ANOVA Tukey test).
TABLE 3. Experiment 1: ANOVA for biomass of $C$. $m a c u$ losa grown in competition with either a conspecific or $F$. idahoensis plant, with two AM treatments (present or absent).

\begin{tabular}{lcrrc}
\hline \hline \multicolumn{1}{c}{$\begin{array}{c}\text { Source of } \\
\text { variation }\end{array}$} & df & $\begin{array}{r}\text { Mean } \\
\text { square }\end{array}$ & \multicolumn{1}{c}{$F$} & $P$ \\
\hline Competitor species & 1 & 45.196 & 42.521 & 0.000 \\
AM fungi & 1 & 0.617 & 0.581 & 0.449 \\
Competitor $\times$ AM & 1 & 7.232 & 6.804 & 0.012 \\
Total & 57 & 1.933 & & \\
\hline
\end{tabular}

ence of AM fungi depended on which competitor was present (Fig. 2, Table 3). Arbuscular mycorrhizal fungi tended to decrease C. maculosa biomass in the presence of a conspecific, but tended to enhance C. maculosa biomass in the presence of $F$. idahoensis. AM fungi decreased the root : shoot ratio of C. maculosa (Fig. 2, Table 4). When these ratios were examined allometrically, the natural $\log$ of root weight and shoot weight were correlated $\left(r^{2}=0.59\right)$, and there was no difference between the slopes for root-shoot relationships of the AM treatments $(P=0.63)$. However, the intercepts differed significantly $(P=0.01)$, suggesting that the differences in root: shoot ratios may have been due to allometric shifts in response to the AM fungal treatment.

\section{Experiment 2}

Bonomyl application significantly reduced mycorrhizal colonization (after McGonigle 1990) of roots from an average of $32.9 \pm 6.3 \%$ ( $1 \mathrm{SE}$ ) to $9.8 \pm 3.4 \%$ for $F$. idahoensis (one-way ANOVA, $\mathrm{df}=1,21 ; P=$ $0.004)$ and from $34.6 \pm 5.9 \%$ to $4.0 \pm 1.4 \%$ for $C$. maculosa in this experiment (one-way ANOVA, $\mathrm{df}=$ $1,21 ; P<0.001)$. Festuca idahoensis biomass was not affected by the presence of AM fungi in this experiment ( $t$ test, df $=14, P<0.818$; Fig. 3 ); however, the biomass of $C$. maculosa that were grown with large, established $F$. idahoensis was $66 \%$ larger when AM fungi were present ( $t$ test, $\mathrm{df}=14, P=0.025$; Fig. 3). AM fungi did not alter root: shoot ratios of $C$. maculosa ( $t$ test, $P=0.084$ ) or large $F$. idahoensis ( $t$ test, $\mathrm{df}=14$, $P=0.741)$.

\section{Experiment 3}

Bonomyl reduced AM fungal colonization of $C$. maculosa roots from $21.0 \pm 3.3 \%$ to $2.5 \pm 1.3 \%$

TABLE 4. Experiment 1: ANOVA table for the effect of AM fungi and competition with either a conspecific or a small $F$. idahoensis plant, on the root : shoot ratio of C. maculosa.

\begin{tabular}{lcccc}
\hline \hline \multicolumn{1}{c}{$\begin{array}{c}\text { Source of } \\
\text { variation }\end{array}$} & df & $\begin{array}{c}\text { Mean } \\
\text { square }\end{array}$ & $F$ & $P$ \\
\hline Competitor species & 1 & 0.204 & 0.406 & 0.527 \\
AM fungi & 1 & 4.242 & 8.476 & 0.005 \\
Competitor $\times$ AM & 1 & 1.912 & 3.821 & 0.056 \\
Total & 57 & 0.595 & & \\
\hline
\end{tabular}




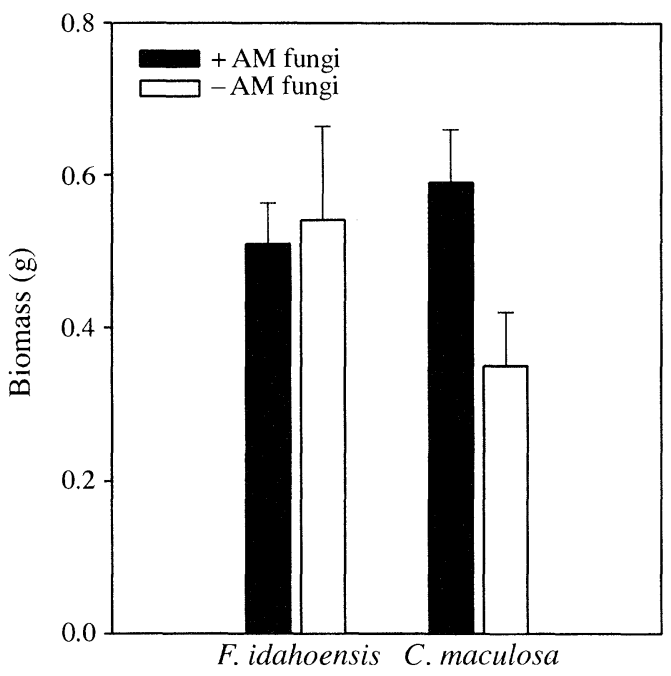

FIG. 3. Experiment 2: Total biomass of C. maculosa and large $F$. idahoensis when grown in competition with one another, and with and without AM fungi. Error bars represent +1 SEM.

(1 $\mathrm{SE} ; t$ test, $\mathrm{df}=7, P=0.019)$, but AM fungal treatments did not significantly affect final C. maculosa biomass in either phosphorus treatment (Table 5). In contrast to Experiment 1, root: shoot ratio was not affected by AM fungi, but increased in the organic phosphorus treatment (Table 6, Fig. 4). The natural log of root weights and shoot weights were correlated $\left(r^{2}=\right.$ $0.88)$. Neither the slope $(P=0.74)$ nor intercept $(P=$ $0.38)$ differed significantly between $P$ treatments, indicating that the differences were due to differences in growth between treatments, rather than allocation differences.

\section{Discussion}

AM fungi had no direct effect on the biomass of either $C$. maculosa or $F$. idahoensis, but substantially increased the competitive effect of $C$. maculosa on $F$. idahoensis. Furthermore, AM fungi had a much stronger impact on C. maculosa's growth, when paired with large $F$. idahoensis than with small $F$. idahoensis. When both species were started from seed, the presence of AM fungi during interspecific competition had a substantial negative impact on $F$. idahoensis, while $C$. maculosa showed a marginal increase in growth (sig-

TABLE 5. Experiment 3: ANOVA table for effects of phosphorus source (available or unavailable) and presence of AM fungi on $C$. maculosa biomass.

\begin{tabular}{lrrcc}
\hline \hline $\begin{array}{c}\text { Source of } \\
\text { variation }\end{array}$ & df & $\begin{array}{c}\text { Mean } \\
\text { square }\end{array}$ & $F$ & $P$ \\
\hline AM fungi & 1 & 0.100 & 2.351 & 0.134 \\
Phosphorus & 1 & 0.015 & 0.364 & 0.550 \\
AM $\times$ phosphorus & 1 & 0.003 & 0.075 & 0.786 \\
Total & 39 & 0.042 & & \\
\hline
\end{tabular}

TABLE 6. Experiment 3. ANOVA table for the effects of AM fungi and phosphorus availability on the root: shoot ratio of C. maculosa.

\begin{tabular}{lcccc}
\hline \hline $\begin{array}{c}\text { Source of } \\
\text { variation }\end{array}$ & df & $\begin{array}{c}\text { Mean } \\
\text { square }\end{array}$ & $F$ & $P$ \\
\hline AM fungi & 1 & 0.029 & 3.022 & 0.091 \\
Phosphorus & 1 & 0.072 & 7.420 & 0.010 \\
AM $\times$ phosphorus & 1 & 0.005 & 0.483 & 0.492 \\
Total & 38 & 0.012 & & \\
\hline
\end{tabular}

nificant interaction effect). In the Experiment 2, large $F$. idahoensis showed no response to AM fungi, whereas $C$. maculosa biomass increased by more than half, in comparison to the nonmycorrhizal treatment. Our results fit theoretical predictions (Allen and Allen 1990) that AM fungi provide a greater benefit to plants with taproots than to those with fibrous root systems, but in this case, the benefits were indirect.

The fact that $C$. maculosa responded to mycorrhizae only in the presence of $F$. idahoensis, and much more when the $F$. idahoensis neighbor was large, suggests that mycorrhizal fungi may have mediated a parasitic interaction. In addition to altering competitive hierarchies by directly enhancing nutrient uptake, mycorrhizae can translocate nutrients or photosynthate between plants (Chiarello et al. 1982, Francis and Read 1984, Walter et al. 1996, Watkins et al. 1996b, Simard et al. 1997). This may be how C. maculosa gains advantage in our system. If so, it is not surprising that the large $F$. idahoensis did not respond negatively in Experiment 2, since it is a slow growing perennial, and the study was relatively short in duration. However, since photosynthate transfer, in general, is poorly understood (Watkins et al. 1996a), and since we did not directly measure translocation of resources, we cannot conclude that this mechanism is responsible for our

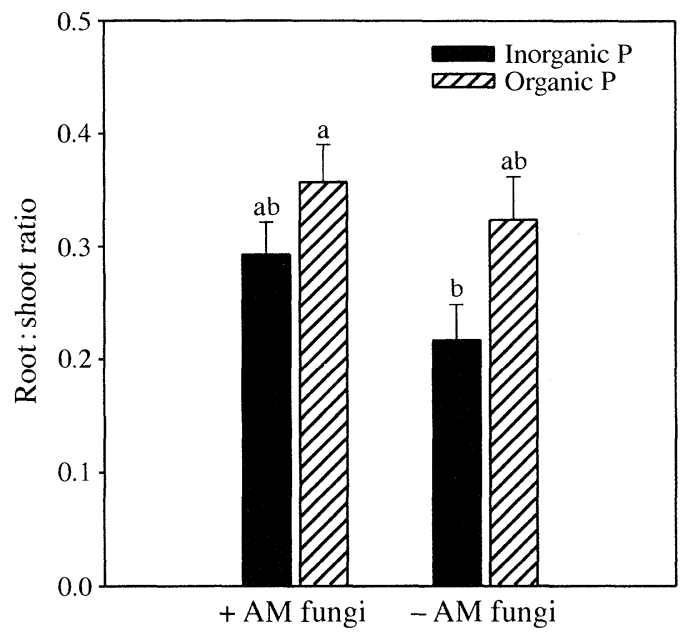

FIG. 4. Experiment 3: Root: shoot ratio of C. maculosa when grown alone, with either available or unavailable phosphorus, with and without AM fungi. 
results. Improved competition for other resources, such as nitrogen, may be equally or more important.

It is surprising that neither species was directly affected by AM fungi, since they are infected under natural conditions. Arbuscular mycorrhizal fungi often improve phosphorus acquisition, but AM fungi did not improve the growth of $C$. maculosa, even when only organic phosphorus was added. However, the lack of response may have been due to our experimental conditions ( $\mathrm{P}$ may not have been limiting in either treatment), or $\mathrm{P}$ acquisition may not be an important role of mycorrhizae on $C$. maculosa. Mycorrhizae engage in dynamic interactions that can range from antagonism to true mutualism (Bronstein 1994, Thompson 1994, Johnson et al. 1997), and the function of AM fungi associated with these species may fall near the center of this continuum. Furthermore, AM fungi may provide other benefits such as protection for host roots from saprophytic fungi and other soil pathogens (Newsham et al. 1995).

We observed statistically significant differences in root : shoot ratios for $F$. idahoensis and $C$. maculosa in Experiment 1, as well as for C. maculosa in Experiment 3 . The shift in root: shoot ratio in Experiment 3 suggests a response to reduced phosphorus availability. However, biomass partitioning in plants is often size dependent (Coleman et al. 1994), and data must be examined allometrically to determine if differences in root: shoot ratios are the result of decreased growth and delayed development, or of reallocation in response to limiting resources (Bazzaz et al. 1989, Coleman et al. 1994). Our allometric analysis indicates that the differences in root: shoot ratios between AM fungal treatments for $C$. maculosa in Experiment 1 may have been due to reallocation, but the remaining differences in allocation patterns are probably a reflection of decreased growth in certain treatments.

Our results demonstrate strong indirect effects, but we could not detect direct effects of AM fungi on $C$. maculos $a$ and $F$. idahoensis. This is unusual, as strong indirect interactions are generally mediated by strong direct effects. This generality, which appears to be widespread within and between trophic levels (Paine 1974, Lubchenco 1978, Hay et al. 1983, Cottam et al. 1986, Brown and Heske 1990, Huntly 1991, Miller 1994) was not supported by our study.

Many studies have found that AM fungi promote species diversity (Grime et al. 1987, Hetrick et al. 1989, 1990, Hartnett et al. 1993, Zobel and Moora 1995, Moora and Zobel 1996). In this study, AM fungi favored the invader $C$. maculosa, which was the dominant competitor, even in the absence of AM fungi. Hoffman and Mitchell (1986) and Halvorson and Koske (1987) found invasive plants to be colonized with AM fungi, but few if any studies have experimentally addressed whether AM fungi contribute to competitive dominance. Field experiments are necessary to solidify our understanding of mycorrhizae as a significant factor in this system, but our evidence indicates that in situ soil fungi increase the ability of an exotic invader to suppress a native competitor.

\section{ACKNOWLEDGMENTS}

We thank Lauren Quinn and Todd Wojtowicz for hours (and hours) of help with this project. Thanks to Jodee Smith, Erik Aschehoug, and TJ Fontaine for greenhouse assistance, and Anna Sala, Eileen Carey, and James Gannon for critical readings of this manuscript. The comments of N. C. Johnson, J. Coleman, and two anonymous reviewers greatly improved this paper. This work was supported in part by NSF EPSCoR grant OSR-955450.

\section{Literature Cited}

Allen, E. B., and M. F. Allen. 1984. Competition between plants of different successional stages: mycorrhizae as regulators. Canadian Journal of Botany 62:2625-2692.

Allen, E. B., and M. F. Allen. 1988. Facilitation of succession by the nonmycotrophic colonizer Salsola kali (Chenopodiaceae) on a harsh site: effects of mycorrhizal fungi. American Journal of Botany 75:257-266.

Allen, E. B., and M. F. Allen. 1990. The mediation of competition by mycorrhizae in successional and patchy environments. Pages 367-389 in J. B. Grace and D. Tilman, editors. Perspectives on plant competition. Academic Press, New York, New York, USA.

Allen, E. B., M. F. Allen, and C. F. Friese. 1988. Responses of the nonmycotrophic plant Salsola kali to invasion by vesicular-arbuscular mycorrhizal fungi. New Phytologist 111:45-49.

Bazzaz, F. A., K. Garbutt, E. G. Reekie, W., E. Williams. 1989. Using growth analysis to interpret competition between a $\mathrm{C}_{3}$ and a $\mathrm{C}_{4}$ annual under ambient and elevated $\mathrm{CO}_{2}$. Oecologia 79:223-225.

Bever, J. D. 1994. Feedback between plants and their soil communities in an old field community. Ecology 75:19651977.

Bever, J. D., J. B. Morton, J. Antonovics, and P. A. Schultz. 1996. Host dependent sporulation and species diversity of mycorrhizal fungi in a mown grassland. Journal of Ecology 84:71-82.

Bronstein, J. L. 1994. Our current understanding of mutualism. The Quarterly Review of Biology 69:31-51.

Brown, J. H.and E. J. Heske. 1990. Control of a desertgrassland transition by a keystone rodent guild. Science 250: 1705-1707.

Caldwell, M. M., D. M. Eissenstaat, J. H. Richards, and M. F. Allen. 1985. Competition for phosphorus: differential uptake from dual-isotope labeled soil interspaces between shrub and grass. Science 217:941-943.

Chiarello, N., J. C. Hickman, and H. A. Mooney. 1982. Endomycorrhizal role in interspecific transfer of phosphorus in a community of annual plants. Science 217:941-943.

Coleman, J. S., K. D. M. McConnaughay, and D. D. Ackerly. 1994. Interpreting phenotypic variation in plants. TREE 9: $187-190$

Cottam, D. A., J. B. Whittaker, and A. J. C. Malloch. 1986. The effects of chrysomelid beetle grazing and plant competition of growth of Rumex obtusifolius. Oecologia 70: 452-456.

DeLucia, E. H., R. M. Callaway, E. M. Thomas, and W. H. Schlesinger. 1997. Mechanisms of $\mathrm{P}$ acquisition for ponderosa pine under different climatic regimes. Annals of Botany 79:111-120.

Estes, J. A. 1978. Sea otter predation and community organization in the western Aleutian Isiands, Alaska. Ecology 59:822-833.

Francis, R., and D. J. Read. 1984. Direct transfer of carbon 
between plants connected by vesicular-arbuscular mycorrhizal mycelium. Nature 307:53-56.

Francis, R., and D. J. Read. 1994. The contributions of mycorrhizal fungi to the determination of plant community structure. Plant and Soil 159:11-25.

Goodwin, J. 1992. The role of mycorrhizal fungi in competitive interactions among native bunch grasses and alien weeds: a review and synthesis. Northwest Science 66:251260.

Griffith, D., and J. R. Lucey. 1991. Economic evaluation of spotted knapweed (Centaurea maculosa) control using picloram. Journal of Range Management 44:43-47.

Grime, J. P., J. M. L. Mackey, S. H. Hillier, and D. G. Read. 1987. Floristic diversity in a model system using experimental microcosms. Nature 328:420-422.

Halvorson, W. L., and R. E. Koske. 1987. Mycorrhizae associated with an invasion of Erechtites glomerata (Asteraceae) on San Miguel Island, California. Madrono 3:260 268.

Hartnett, D. C., B. A. D. Hetrick, G. W. T. Wilson, and D. J. Gibson. 1993. Mycorrhizal influence of intra- and interspecific neighbor interactions among co-occurring prairie grasses. Journal of Ecology 81:787-795.

Hay, M. E., T. Colburn, and D. Drowning. 1983. Spatial and temporal patterns in herbivory on a Caribbean fringing reef: the effects of plant distribution. Oecologia 65:591-598.

Hetrick, B. A. D., G. T. Wilson, and D. C. Hartnett. 1989. Relationship between mycorrhizal dependence and competitive ability of two tallgrass prairie grasses. Canadian Journal of Botany 67:2608-2615.

Hetrick, B. A. D., G. W. T. Wilson, and T. C. Todd. 1990. Differential responses of C 3 and C4 grasses to mycorrhizal symbiosis, phosphorus fertilization, and soil microorganisms. Canadian Journal of Botany 68:461-467.

Hetrick, B. A. D., G. W. T. Wilson, and T. C. Todd. 1992. Relationships of mycorrhizal symbiosis, rooting strategy, and phenology among tallgrass prairie forbs. Canadian Journal of Botany 70:1521-1528.

Hoffman, M. T., and D. T. Mitchell. 1986. The root morphology of some legume spp. in the south-western Cape and the relationship of vesicular-arbuscular mycorrhizas with dry mass and phosphorus content of Acacia saligna seedlings. South African Journal of Botany 52:316-320.

Huntly, N. 1991. Herbivores and the dynamics of communities and ecosystems. Annual Review Ecology and Systematics 22:477-501.

Johnson, N. C. 1993. Can fertilization of soils select for less mutualistic mycorrhizae? Ecological Applications 3:749757.

Johnson, N. C., J. H. Graham, and F. A. Smith. 1997. Functioning of mycorrhizal associations along the mutualismparasitism continuum. New Phytologist 135:575-585.

Johnson, N. C., D. Tilman, and D. Wedin. 1992. Plant and soil controls on mycorrhizal fungal communities. Ecology 73:2034-2042.

Kareiva, P. 1994. Higher order interactions as a foil to reductionist ecology. Ecology 75:1527-1528.

Koide, R. T.and M. Li. 1990. On host regulation of the vesicular-arbuscular mycorrhizal symbiosis. New Phytologist 114:59-74.

Koide, R. T., and R. P. Schreiner. 1992. Regulation of the vesicular-arbuscular mycorrhizal symbiosis. Annual Re- view of Plant Physiology and Molecular Biology 43:557581.

Lubchenco, J. 1978. Plant species diversity in a marine intertidal community: importance of herbivore food preference and algal competitive abilities. American Naturalist 112:23-39.

Marler, M. J. 1997. Mycorrhizae enhance spotted knapweed (Centaurea maculosa) invasion in western Montana. Thesis. University of Montana, Missoula, Montana, USA.

McGonigle, T. P., M. H. Miller, D. G. Evans, G. L. Fairchild, and J. A. Swan. 1990. A new method which gives an objective measure of colonization of roots by vesiculararbuscular mycorrhizal fungi. New Phytologist 115:495501.

Miller, T. E. 1994. Direct and indirect species interactions in an early old-field plant community. American Naturalist 143: 1007-1025.

Moora, M., and M. Zobel. 1996. Effect of arbuscular mycorrhiza on inter- and intraspecific competition of two grassland species. Oecologia 108:79-84.

Muller-Scharer, H., and D. Schroeder. 1993. The biological control of Centaurea species in North America: do insects solve the problem? Pesticide Science 37:343-353.

Newsham, K. K, A. H. Fitter, A. R. Watkinson. 1995. Multifunctionality and biodiversity in arbuscular mycorrhizas. Trends in Ecology and Evolution 10:407-411.

Paine, R. T. 1966. Food wed complexity and species diversity. American Naturalist 100:65-75.

Pennings, S. C., and R. M. Callaway. 1996. Impact of a parasitic plant on the structure and dynamics of salt marsh vegetation. Ecology 77:1410-1419.

Simard, S. W., D. S. Perry, M. D. Jones, D. D. Myrold, D. M. Durall, and R. Molina. 1997. Net transfer of carbon between ectomycorrhizal tree species in the field. Nature 388:579-582.

Thompson, J. 1994. The coevolutionary process. University of Chicago Press, Chicago, Illinois, USA.

Van der Putten, W. H., C. Van Dijk, and B. A. M. Peters. 1993. Plant-specific soil-borne diseases contribute to succession in foredune vegetation. Nature 362:53-55.

Walter, L. E. F., D. C. Hartnett, B. A. D. Hetrick, and A. P. Schwab. 1996. Interspecific nutrient transfer in a tallgrass prairie plant community. American Journal of Botany 83: $180-184$.

Watkins, N. K., A. H. Fitter, J. Graves, T. Brown, and D. Robinson. 1996a. Quantifying carbon transport between mycorrhizally linked plants using natural abundance ${ }^{13} \mathrm{C}$ measurements. Page 125 in T. M. Szaro and T. D. Bruns, editors. Program and Abstracts of the First International Conference on Mycorrhizae. University of California at Berkeley, Berkeley, California, USA.

Watkins, N. K., A. H. Fitter, J. D. Graves, and D. Robinson. 1996b. Carbon transfer between $\mathrm{C}_{3}$ and $\mathrm{C}_{4}$ plants linked by a common mycorrhizal network, quantified using stable carbon isotopes. Soil Biology and Biochemistry 28:471477.

Watson, A. K., and A. J. Renney. 1974. The biology of Canadian weeds. 6. Centaurea diffusa and C. maculosa. Canadian Journal of Plant Science 54:687-701.

Zobel, M., and M. Moora. 1995. Interspecific competition and arbuscular mycorrhiza: importance for the coexistence of two calcareous grassland species. Folia Geobotanic Phytotaxon 30:223-230. 